\title{
English Nouns and Verbs Ending in -scape
}

\section{David L. Gold}

\begin{abstract}
NO ESCAPE "Healthscape, Medscape -this industry always works this way. For a while it was "object this" and "object that," then "net," and even "net object. "These things aren't terribly sophisticated; it's like fashions in children's names. And a good name can add 200 percent to your valuation.'-Esther Dyson, publisher of Release 1.0 , a technology newsletter, on the recent spate of new companies named with the suffix -scape" (New York, 1 April 1996, p. 15).
\end{abstract}

The words mentioned in this article illustrate a phenomenon widespread in the world's languages: a word is borrowed; later it becomes the model for new words in the borrowing language; and still later a suffix is detached from the words containing it for use in the formation of still more words, that is, a productive suffix emerges. Thus, English landscape, which is of Dutch origin, has at least since the eighteenth century served as the model for more words ending in -scape and now -scape is freely usable to coin even more. To my knowledge, the research literature has thrice mentioned the productivization of that suffix:

"From landscape (which is Dutch landschap) resulted scape[,] which is almost entirely used as the second element of combinations, as in seascape (OED, 1799) and later earthscape, cloudscape, sandscape, mountainscape, moonscape, parkscape, cityscape, waterscape, house-scape, roadscape, mindscape" (Hans Marchand, The Categories and Types of Present-Day English Word-Formation, Wiesbaden, Otto Harrassowitz, 1960, par. 4.1 .5$, p. 159).

"[...] what begins as blending can turn into free composition. Thus, English borrowed the Dutch painting term landscape and then formed such parallel terms as cityscape, inscape, offscape, seascape, skyscape, townscape, waterscape, and the independent word scape. Any new term, such as moonscape, is probably not the result of blending, but of compounding" (John Algeo, "Blends, A Structural and Systemic View," American Speech: 
A Quarterly of Linguistic Usage, vol. 52, nos. 1-2, Spring-Summer 1977, pp. 47-64; the quotation is from page 51).

Of the words which Adrienne Lehrer gives ("Scapes, Holics, and Thons: The Semantics of English Combining Forms, "American Speech: A Quarterly of Linguistic Usage, vol. 73, no. 1, 1998, pp. 3-28), I have not found these elsewhere: bridgescape, buildingscape, forestscape, lipscape, phonescape, and rockscape (p. 24; none is defined). All but lipscape and phonescape are immediately understandable. When we read that "many of these words appear in titles of paintings and photographs," we realize that those two words are probably *Lipscape and *Phonescape, that is, the names or parts of the names of paintings or photographs depicting lips and one or more telephones. Lehrer wrongly includes escape among those containing -scape (ibid.).

After the productivization of -scape has come the addition of meanings (as we see at least from Jazzscape, Rosescapes, and Windscape, the depiction in question may not even be visual). From time to time, the suffix is used so loosely that the result is catachrestic (see the quotation at harborscape).

A. F. Brown's Normal and Reverse English Word List (Philadelphia: University of Pennsylvania Press, 8 vols., 1963) lists airscape, cityscape, cloudscape, landscape, manscape, moonscape, offscape, riverscape, seascape, snowscape, townscape, treescape, and waterscape. Given the fact that -scape is a productive suffix, no list of words so ending can be exhaustive. A few more are:

Aqua-Escape, a nonce, is found in "Beyond the Waterfront, and Into the Water: New Explorers Are Dragging Boats Across Sidewalks and Dodging Barges, All for Love of the AquaEscape," the title of an article by Tom Sawyer in The New York Times, 17 September 1995, sec. 13 , p. 2, which deals with people who like to row or paddle boats in the waters of New York City. For another allusion to the word escape see Summer 'Scape and for a possible allusion see Vachtscape. Later, Aquascape became the trademarked name of some kind of water display for homes and offices (so, for example, in a Macy's advertizement in Newsday, 15 April 2001, p. A9).

Artscape. "Artscape 1988" is the name of a cultural festival held in Dutchess County, New York, in 1988. Artscape Long Island is the name of a map and directory of cultural institutions in Nassau and Suffolk counties, New York, published in 1994 by the Long Island Arts Council.

Barnum's Kaleidoscape is the name of Ringling Bros. and Barnum \& Bailey's "performance event" at Bryant Park, in Manhattan, New York, from 22 November to 31 December 2000 (and again in December 2001). Would not either performance or event be enough?

battlescape 'depiction of a battle'. Hence a kind of warscape.

bedroomscape 'view of a bedroom'. "Wakes again. Realizes that Philomena is still gone. Guilt at sleeping so late. Crawls out of bed. Surveys disorderly, depraved bedroomscape. Vows to clean up bedroom. Soon" (Jay MacInerny, "A Typical Morning in the West Village," The New Yorker, 25 December 1995 - 1 January 1996, pp. 74-75; the quotation is from page 74). See roomscape. 
birdscape 'depiction of a bird or birds'. "The drawing range in size from a full sheet to microscopic with groups of several birds to 'bird-scapes' which are composite drawings that can suggest larger birds" ("70,000 Peace-Bird Exhibit Oepns At United Nations Sri Chinmoy Creates 'Bird-Scapes for Peace,'" Queens Examiner, Queens, New York, 3 August 2000, p. 14; the quotation and the headline, quoted here without change, are badly worded and misprinted). A verb is implied in Birdscaping Your Garden, the title of a guide by George Adams published by Rodale Books for people who want to attract birds to their gardens.

bodyscape 'depiction of a body'. Bodyscapes, Incorporated is the name of a fitness center in Manhattan, New York. Bodyscape: Art, Modernity and the Ideal Figure is the name of a book by Nicholas Mirzoeff, published in New York by Routledge in 1995.

brickscape 'depiction of a brick wall' .

Brueghelscape. "What I saw around the stadium was, it seemed to me, an expression of capitalism in its purest form -- not the raw nineteenth-century version that people kept alluding to, cringingly, in recent economic debates all over Poland but something still more primeval. This was the world of Braudel, the fifteenth-century trade fair, a teeming Brueghelscape" (Lawrence Wechsler, "A Reporter at Large: Deficit," The New Yorker, 11 May 1992, pp. 41-77; the article deals with contemporary Poland and the quotation refers to Warsaw).

B-scape 'computer-generated image based on protective athletic equipment [made by Hani Rashid and Lisa Anne Couture]' (Grace Glueck, "'Compression,' "The New York Times, 5 January 2001, p. E41),

castlescape 'depiction of a castle'.

cavescape 'depiction of a cave' (The New York Times Book Review, 16 October 1988, p. 13).

Celeb-Scape. "CELEB-SCAPE: Every week, thousands of you phone our 'Who's News' hot line to ask about celebrities. Come online next Sunday at 1 p.m. ET, and 'Who's News' editor Lorrie Lynch will answer your questions live in our first interactive chat. Watch for more live events with celebrities and newsmakers" (USA Weekend, 20-22 October 1995, p. 9).

cityscape. In "this travesty upon the cityscape" (The New York Times, 5 January 1978, p. C1) and "more dramatic changes in the cityscape" (ibidem) the word refers to the urban landscape, not a painting. Cityscape is the name of a regular feature in Mexico City, a periodical published in Mexico City, Mexico. It is the name of a "gentlemen's club" in Queens, New York (with two locations, at 2700 Queens Plaza, Long Island City, and 62-05 30 Avenue, Woodside). See Peoplescape and Queenscape.

countryscape 'depiction of the countryside'. "For finding the poetry in this slow, languorous countryscape, Ms. Clay deserves much credit" (Grace Glueck, review of Delta Land [an exhibit of paintings by Maude Schuyler Clay], The New York Times, 30 June 2000, p. E37). 
cowscape 'depiction of a cow or cows'.

Cyberscapes is the name of a course which Mark Taylor teaches at Williams College on the philosophical and cultural implications of the information revolution, from Kant to Warhol to the Internet.

deathscape. "Oblivious to the deathscapes ravaging Jewish lives in Europe, little Judith soon shuttled joyfully between her own home and her neighbor's always asking first, 'Maman, can I come?" (Caryn Eve Murray, "Queens Diary: Finding 'Maman': Kew Gardens immigrant rejoins woman who hid her from Nazis," New York Newsday, 5 June 1994, p. 3). Since deathscapes cannot ravage, the word is misused here. " 'Something happened' to Homer in his mid-40s? Surely I'm not the first to suggest that he realized he was gay but couldn't accept it. How many dark, lonely, gloomy deathscapes would a guy paint because one babe informed him they were "just friends'?" (Jerry Loyd, letter to the editor, National Geographic, April 1999). See gravescape.

desertscape 'depiction of a desert'. Semantically akin words are dunescape and sandscape.

dogscape 'depiction of a dog or dogs'.

dramascape. "The dramascapes of Louis Lozowick and Adolf Dehn" (The New York Times Book Review, 21 November 1982, p. 29).

dreamlandscape and dreamscape 'dreamlike depiction'. "He scored a notable success in 1945 with his exhibition of Miró's 29 ebullient 'Constellations' drawings in watercolor and gouache (1940-41); they are among Miró's greatest achievements. Two of these sprightly dreamscapes are on view here, 'Acrobatic Dancers' and 'Figures at Night, Guided by the Phosphorescent Tracks of Snails'" (Grace Glueck, "Art Review: View of the Other Matisse: Dealer, Patron and Son," The New York Times, 22 February 2002, p. E39). Dreamscape is the name of a 1964 American film. Dreamlandscape, lunarlandscape, and moonlandscape were probably ephemeralisms, now replaced by the more compact dreamscape, lunarscape, and moonscape.

dumpscape. "Dumpscape" is the caption of a photograph of a dumping ground in New York of 7 February 1983 (p. 46). "Elegy to a Dumpscape" is the title of an article about the Fresh Kills landfill by Verlyn Klinkenborg in The New York Times Magazine of 10 October 1999 (pp. 74-75). See Lifescape.

dunescape. "Dunescape, Saudi Arabia" is the caption of the photograph opposite page 1 of David C. Knight's The First Book of Deserts: An Introduction to the Earth's Arid Lands (New York, Franklin Watts, Inc. 1964). Dunescape is the name of the urban beach which opened on 2 July 2000 in Long Island City, New York (William L. Hamilton, "In This Artwork, Tan's The Favorite Color," The New York Times, 6 July 2000, pp. F1 and F4). Fifth of the ten best designs in 2000 according to Time was "PS1'S TEMPORARY DUNESCAPE OUTDOOR SUMMER PAVILION Architect firm SHoP's temporary 'urban beach' in Queens, N. Y., became an inviting summer sensation. Made from 6,000 2-in. by 2 -in. boards that rolled, twisted and slid about, it offered wet and dry places for visitors to bask, wade and escape the sun. It was an architectural 
drawing come to life" (quoted verbatim from Time, 18 December 2000, p. 85). "DUNESCAPE The Kutchin house [...]" is the caption of a photograph of a house situated on a dune in The New York Times of 6 September 2001 (p. F6). Semantically akin words are desertscape and sandscape.

dustscape. "[Jonathan] Callen is also showing a 'dustscape'--white cement powder that's been sifted through a template to form a Persian rug-ish pattern on the floor. At Nocole Klagsbrun, 526 West 26th Street; September 8 through October 14" (caption of an illustration, New York, 18 September 2000, p. 99).

fanscape. "Ross Lewis, the artist who created 'fanscapes,' an installation of nine windactivated nylon fans, visiting Belvedere Castle in Central Park to see if the summer storms had damaged his sculptures" is the caption of a photograph in The New York Times of 31 January 1993 (p. 24).

fantasyscape 'surrealistic depiction'.

Farscape is the name of an American science-fiction television series (fl. 2001) about an astronaut from Earth fighting battles on "the other side" (the far side) of the Universe.

fleshscape 'depiction of a body or part of one'.

flowerscape 'depiction of a flower or flowers'. FLOWERscape is the name of a "computer program that eliminates guesswork! Colorful photographs help select your year-round garden. View its growth in any month!" (advertizement in American periodicals, March 1996) or, according to another American advertizement, "Don't get caught with your plants down! Make the most of your flower garden by simply entering your geographic location. FLOWERscape recommends suitable choices from its colorful library of plant photos. Preview your garden's growth during any month."

foodscape 'depiction of food'. The word is used figuratively in "A gourmet foodscape is spreading through a metropolis famously given to the canned and frozen" (New York, 27 December 1982 - 3 January 1983, p. 62), that is, good restaurants and food stores are opening in a city noted for its unimaginative food.

Geoscape. The New York Times of 22 September 1987 reported that Evelyn Rosenberg had created a 21-foot-wide frieze which she called "Evolutionary Geoscape -- Monoblast I" (p. C9).

Grandscape is the title of a landscape painting which serves to advertize Grand Marnier Liqueur (at least in 1994).

gravescape. "Perhaps we are unduly nervous. (I'd even had a small anxiety attack, waiting for my connection at O'Hare.) The problem is not the Poland we've come to, but the Poland my brother, Steven, and I have brought with us, the one we carry with us as Jews. Inherited from our grandparents, this Poland is a dark gravescape, a terrifying labyrinth of memory, filled with 
pogroms and blood libels" (Joseph Skibell, "In Poland, Invisible Others," The New York Times Magazine, 8 November 1998, part 2, pp. 28-33; the quotation is from page 28). See deathscape.

harborscape 'depiction of a harbor'. We have catachresis in the sentence "At West 10th Street, a line of barges sold oysters to people strolling through the harborscape" (Richard F. Shepard, "And a Fine Brawling City It Was!," The New York Times, 31 July 1994, sec. 4, p. 4). Harbor is enough here.

hardscape "the manufactured or constructed objects in a designed landscape, such as paving stones, benches, and fountains' (so defined in Third Barnhart Dictionary of New English). A landscape architects' term, also definable as 'humanmade objects in a landscape'. See softscape.

hell-landscape. "Entered the Strait of Le Maire, \& through the short day had a fine view of the land on both sides -- Horrible snowy mountains -- black, thunder-cloud woods -- gorges -- helllandscape" (Herman Melville, journal entry for 7 August 1860 at Cape Horn, quoted on pages 621622 of volume 2 of Jay Leyda, The Melville Log: A Documentary Life of Herman Melville, 18191891, 2 vols., New York, Harcourt, Brace and Company).

highwayscape "depiction of a highway'. "Cityscape/Highwayscape" is the name of a painting by Jason Brockert, an American.

Homescapes is the name of a store selling home furnishings in Cooperstown, New York.

horizonscape 'depiction of a horizon' (The New York Times Magazine, 23 August 1992, p. 35).

icescape 'depiction of ice, especially of the polar landscape'.

industryscape 'depiction of a factory, a factory scene, or an industrial area'.

Inner-City Scapes: Tri-Dimensional Constructions was the name of an exhibit of artwork by Jeff Pullen at the Ollantay Gallery, Queens, New York, in June 1992.

inscape, a term in the esthetics of Gerard Manley Hopkins (who coined this word as well as lovescape), is discussed by Samuel Hazo in Princeton Encyclopedia of Poetry and Poetics (Princeton, Princeton University Press, revised edition, 1974, p. 396); see also American Speech: A Quarterly of Linguistic Usage, vol. 52, 1977, p. 51, and the second edition of the Oxford English Dictionary (1989). The word is also an art term meaning 'depiction of an interior'. Inscape Study Centre is the name of a school of interior design with branches in Johannesburg and Cape Town, South Africa. Inscape is the name of a musical composition by Aaron Copeland. See offscape.

Interscape (2000) is the name of a dance piece by Merce Cunningham which premiered on 6 April 2000 (Anna Kisselgoff, "Dance Review: Multihued Creature Afoot With John Cage," The New York Times, 10 April 2000, p. E5). Does this name ailude to the Internet? 
Jazzscape is the name of the jazz festival held in Bermuda on 11-12 October 1996. More words referring to music are soundscape, tunescape, and Windscape.

junglescape 'depiction of a scene in a jungle'.

lakescape 'depiction of a lake'.

Langscape is the name of the quarterly newsletter of Terralingua, an international advocacy organization that supports research and education about linguistic and biological diversity. While containing a clipping of language, the name seems also to allude to the word landscape.

lawnscaping is used at least in lawnscaping gardener. Lawnscapes is the name of a lawn-care company in Bloomington, Indiana. See roofscaping.

Lifescape. According to the caption (entitled "The Finalists: Fresh Designs") of the photograph accompanying Denny Lee's "At Fresh Kills Landfill, Garbage Out, Grand Plans In" (The New York Times, 9 December 2001, City Section, p. 6), Landscape is the name of one of the six designs making it to the final round in the competition whose aim is to find the best master plan for transforming the Fresh Kills Land Fill, a garbage dump in Staten Island, New York, that stopped taking the city's trash in March 2001. The design was submitted by Field Operations (of Philadelphia, Pennsylvania), which said the aim of its proposal was to provide "A green matrix of infinite horizons and newly connected ecosystems." According to "Staten Island: Fresh Kills Design Contest" (The New York Times, 20 December 2001, p. D4), Lifescape was one of the three designs making it to the final round (the earlier report, therefore, must have meant the semifinal round); according to Lee, the three finalists will have the right to negotiate a contract with the city government. See Dumpscape.

lovescape was coined by Gerard Manley Hopkins, who hyphenated the word. It is also an art term meaning 'depiction of lovers'. See inscape for another of Hopkins's coinages.

lunarlandscape and lunarscape 'depiction of the surface of the Moon'. See the remark at dreamlandscape.

mallscape. "It is the familiar mallscape of suburbia, a big supermarket and a strip of gleaming shops behind a parking lot the size of a football field. But it is a stone's throw from a public housing tower. This is 47th Street in the pock-marked North Kenwood section of Chicago, where the population has dwindled by two-thirds in the last 30 years, with whole blocks sitting vacant, rejected as untouchable by investors who saw more danger than hope" (Dirk Johnson, "A Suburbiascape Grows In Inner-City Chicago," The New York Times, 20 October 1999, p. A18).

manscape [quotation mislaid].

marinescape 'seascape'. 
mediascape. "But they also lament an End of Days, when the old civil culture of good prose and good taste met a brand-new mediascape of unbearable lightness and free-fall spin; when static cling met buzz. The horror! The horror!" (John Leonard, "Eustace Tilley, Call Home," The New York Times Book Review, 13 February 2000, pp. 6-7; the quotation is from page 6). Mediascape (capitalized) is the name of a show of fourteen media-oriented works of art (incorporating video, virtual reality and computer-generated images) held at the downtown branch (in $\mathrm{SoHo}$ ) of the Guggenheim Museum (Manhattan, New York) during the summer of 1996.

Medscape is the name of an electronically published medical journal (at least since 1999) and Medscape Inc. is the name of a dot-com company (at least since January 1999).

memoryscape. "With W. G. Sebald's haunting new book, 'Austerlitz,' we are transported to a memoryscape -- a twilight, fogbound world of half-remembered images and ghosts that is reminiscent at once of Ingmar Bergman's 'Wild Strawberries,' Kafka's troubling fables of guilt and apprehension and, of course, Proust's 'Remembrance of Things Past' " (Michiko Kakutani, "Books of The Times: In a No Man's Land of Memories and Loss" [review of W. G. Sebald, Austerlitz, New York, Random House, 2001], The New York Times, 26 October 2001, p. E42).

Me-scape. "Installation: Me-scapes" is the title of the caption of a photograph in New York of 12 April 1999 reading "Artist Mariko Mori is a beached, blue-haired mermaid in Empty Dream (left), one of several billboard-size, computer-manipulated photographic tableaux-installations on view in Mori's first New York museum exhibition. At the Brooklyn Museum of Art [... ]" (p. 105).

Metroscape Systems is the name of a group of gardening contractors in New York City in the 1980 s that has since closed. In the computer age, system is a fashionable word.

MicroScapes was the name of an exhibit of high technology organized by AT\&T in March 1993.

mindscape 'depiction of a scene imagined by the mind'. Mindscape is the name of a publisher of computer programs. Atcheson L. Hench writes in "Mindscape" (American Speech, vol. VI, no. 4, April 1931, pp. 253-254): "Recently Mr. Lee Wilson Dodd used the word mindscape ('No Thoroughfare' in The Saturday Review of Literature, Dec. 27, 1930, p. 486), a rare word or a coinage of his own, I do not know which. He was criticizing a poem for its unintelligibility. 'There is No Thoroughfare' to the poet's meaning, he said. 'The road is permanently barred.' 'One may, of course strive to peer through slight cracks and knotholes in the fence, and so obtain a meager impression--starved, wry glimpses--of the private mindscape beyond! But is it worth the trouble of the effort, since free communication has been so wilfully forbidden?' 9 The word was very appropriate. Mr. Dodd saw the poet's mind as a landscape with its hills and valleys, and its lights and shadows. His usage of the word is of the sort that makes one say instinctively, 'The right word! The very right word for the place.'". A nightmarescape is a kind of dreamscape, which is a kind of mindscape. See psychoscape.

moodscape 'depiction of a person in a particular mood'. 
moonlandscape 'lunarlandscape, lunarscape'. See the remark at dreamlandscape.

moonscape has the same denotation as lunarscape but not the same connotation since moonscape is the poetic word and lunarscape the pedestrian one. Hence moonscape, not lunarscape, is used in Annemarie Koenigsberger's poem cited at stonescape. Moonscape is also used in a transferred sense, 'bleak place [as something viewed]', as in "A Mexican boy above the parched, crowded moonscape of Juárez's Anapre colonia" (Time, 11 June 2001, p. 65), "Refugees: Pakistan Readies Forbidding Moonscape of Rock for 10,000 Afghans" (the title of an article by Barry Bearak in The New York Times, 5 October 2001, p. B3), and, referring to global warming, "Scientists had feared that we'd go from some intact forest to moonscapes, but that's not likely to happen" (John Tierney, "The Big City: Warming Up To The Notion Of Warming," The New York Times, 7 December 2001, p. D1).

mudscape 'depiction of mud'.

namescape 'picture which emerges from a study of names'. "At least as far as onomastics is concerned, Vogel's major contributions are toward our understanding of the tremendous impact, the scope and dimensions of which we have not yet fully realized, of ethno-history on the American namescape, in particular the implications of the legacies of names left by the relationships between Indians and Whites" (Names 42, 2, June 1994, p. 134). Roger L. Payne uses the word in his "Geographical Names Activity in the United States" (Namenforschung / Name Studies / Les noms propres / Ein internationales Handbuch zur Onomastik / An International Handbook of Onomastics /Manuel internationald'onomastique, ErnstEichler, Gerold Hilty, Heinrich Löffler, Hugo Steger, and Ladislav Zgusta, eds., Walter de Gruyter, Berlin and New York, 1996, pp. 1133-1141), for example, "The namescape could be quite complex, especially in areas of overlapping Native American tribes and linguistic groups such as in parts of North Carolina and Kentucky" (p. 1134).

Netscape Communications Corporation is the name of an American company producing software for navigating the Internet.

Newscapes Garden Design Inc is the name of a landscaping company in New York City. The first word is a blend of new and landscape.

nightmarescape 'depiction of a nightmare'. Hence a kind of mindscape.

nightscape 'depiction of a night scene'.

offscape. "The glimpses of misty Zen-like offscapes save the day" (The New York Times Magazine, 16 June 1986, p. 78). Inscape and offscape are noteworthy in that their stems are function words, not content words. Lehrer notes that "We do not usually get acceptable words by adding affixes to combining forms (e.g., [... ${ }^{*}$ nonscape 'a view of nothing at all')" (op. cit. p. 15). It would not be surprizing to find a work of modern art called *Nonscape.

outscape [quotation mislaid]. 
peoplescape 'depiction of a scene with many people'. Peoplescape is the name of a department in Los Angeles, a periodical. See Cityscape and Queenscape.

plantscape. "Putting Down Roots: Plantscape designers find their business booming" is the title of an article by Katia Hetter in Newsday, New York, 21 March 1999, pp. F8-F9, about landscape artists who specialize in "interior and exterior plant design. " For example, they choose the plants for rooftop gardens, restaurants, and other public spaces. Plantscapes, Incorporated is the name of a nursery on Long Island, New York, in the 1980s that has since closed.

poemscape [quotation mislaid].

prisonscape 'depiction of a prison or of a prison scene'.

psychoscape 'mindscape'.

Queenscape is the name of a series of articles about Queens neighborhoods in New York Newsday, 1990-1991. See Cityscape and Peoplescape.

roofscape 'depiction of a rooftop scene'. A caption in The New York Times of 12 July 1998 reads "Three rooftop additions, side by side, on Harrison Street. TriBeCa's roofscape is rife with houselike structures and entire new floors" (Real-Estate Section, p. 1), where the word refers not to a depiction but to a view. English also has the verb roofscape 'landscape rooftops [as of apartment houses and office buildings]', the agentive noun roofscaper 'person who roofscapes', and the verbal noun roofscaping 'landscaping of rooftops'. See lawnscaping.

roomscape 'depiction of a room'. One time in the 1980s (exact date mislaid), a New York City department store advertized its July white sale by publishing an illustration it called "Roomscapes." Roomscapes in the name of a professional memoir by Renzo Mongiardino, an interior designer, written in collaboration with Fiorenzo Cattaneo and published by Rizzoli in 1993. See bedroomscape.

Rosescapes is the name of a collection of sonnets about roses by Edward L. Conaty, Jr., published by Vantage Press (New York) in 1993.

sandscape. See American Speech: A Quarterly of Linguistic Usage, vol. 46, 1977, p. 99.

seascape 'depiction of an ocean scene'. The Seascape is the name of a restaurant and tap room in Islip, New York, during the 1980s (it faced the Atlantic Ocean). Is it the same establishment as the one in that town now called Seascape Inn? A motel in Montauk, New York, is called Seascape Motel and a business in Smithtown, New York, is called Sescape Dive Center of Smithtown. See Seescape.

sea-cum-strandscape 'depiction of an ocean and beach scene'. 
Seescape is a nonce word used in an advertizement in The New York Times of 24 September 1995 , sec. 2, p. 8, calling attention to the coverage of art in that newspaper. Perdido Beach, Alabama, has a resort called Seescape, which is probably a misspelling of Seascape.

Shescape is the name of a floating lesbian bar which sailed from Manhattan to The Hamptons and back at least during the early 1990s (in that sense, the word puns on seascape) and the name of a shop (presumably selling women's clothing) once with branches at 41 East 58 Street and 235 West 75 Street and now at 101 Lexington Avenue (all in Manhattan, New York).

Silkscapes Inc, is the name of a store in Manorville, New York, that sells silks.

skinscape. "My skin-scape turned tropical: huge bruises bloomed like orchids, luxuriated for weeks" (Inga Clendinnen, Tiger's Eye: A Memoir, New York, Charles Scribner's Sons, 2001).

skyscape. "Juxtaposed against the towering skyscape of Wall Street is the restored South Street Seaport" (Newsday, New York, 2 February 1986, p. 5). "The tower's projecting attic floors, mansarded roof and lantern long remained a characteristic figure in the New York skyscape" (Iim O'Grady, "The Lost City, Revisited Yet Again," The New York Times, 6 August 2000, City Section, p. 2).

slumscape 'depiction of a slum'. Hence a kind of cityscape and urbanscape.

smearscape. "Chroma Smearscapes" is the title of a group of $8 \frac{1}{2}-$-by-11-inch papers by Lucas Samaras (Grace Glueck, review, The New York Times, 28 December 2001, p. C44).

softscape 'naturally occurring objects in a landscape, like grass and trees'. A landscape architects' term. See hardscape.

soundscape 'range of sounds; musical panorama' (so defined in Third Barnhart Dictionary of New English). Soundscape was the name of a New York City cabaret in the 1980s that has since closed. "New Age Come of Age: Dreamy Soundscapes Offer Relief from Formula Pop and Rock" is the title of an article in The New York Times of 1 September 1986 (p. 82); the word is not used in the article itself. No later than July 1994 the Ensoniq Soundscape sound card, a computer application, was on the market in the United States. "A Soundscape That Ranges From Grunts to Gospel Songs" is the title of Lawrence Van Gelder's review of the Classic Stage Company's "You Say What I Mean but What You Mean Is Not What I Said" (The New York Times, 23 January 1997, p. C18). "A soundscape of space, elongation and silence" is the subtitle of Peter Watrous's "Jazz Review: Miles Davis Disciple Evokes Sensuality With a Hint of a Moan" (The New York Times, 3 December 1997, p. E5). "[... ] brooding urban soundscapes of English trip-hop and New York's Wu-Tang Clan" (Jon Pareles, "Recordings View: French Pop Discovers Its Hip to be Cheesy," The New York Times, 15 March 1998, sec. 2, p. 34; the title indeed has "Its"). An unsigned note in National Geographic of December 1998 is headed "Online: Trek Across a Global Soundscape" and reads "First they heed the call of the wild, then they record it. Field teams for Radio Expeditions, a Society collaboration with National Public Radio, capture sounds and stories from remote corners of the planet. The NPR broadcasts can also be heard online--supplemented by interviews, images, 
and teaching plans--at .../radiox." The catalog of The Sharper Image dated Father's Day 1999 offers "The perfect escape from a hectic, noisy world. Think of our exclusive Heart and Sound Soother relaxation system as your own personal sound environment. The two Ultra models have ten soundscapes, including four nature sounds: North Woods, California Coast, Rain Forest and Tropical Cruise, plus the six original sounds: Heartbeat, Rain, Brook, White Noise, Ocean and Summer Night" (p. 46). "Downtown Reykjavik may resemble an overgrown Maine fishing town, but the soundscape recalls nothing so much as the vanguard ferment of lower Manhattan circa 1980. Everybody under 30 , it seems, is in an art-rock or a space-rock or an experimental-rock band" (Gerald Marzorati, "The experimental-rock band Sigur Ros is the hottest thing in Iceland and the biggest get this year by a U.S. label: Nordic Tracks: How did Reykjavik become a global pop laboratory?," The New York Times Magazine, 22 April 2001, pp. 56-61; the quotation is from page 58).

stairscape 'depiction of stairs; scene created by stairs'. These two sentences appear in Bernard Rudofsky's "In Praise of Stairs" (Horizon, vol. vi, no. 4, autumn 1964, pp. 78-87): "To this day the amphitheatres of antiquity and the vast stairscapes of the Old World are ideal gathering places" (p. 79) and "Some of the finest stairscapes have been composed without benefit of drafting boards" (p. 82).

starscape 'depiction of a starry sky'.

state scapes was a nonce formation used in the title of an announcement in The New York Times of 25 February 1984, p. 14, of an exhibit of prints depicting scenes in New York State.

still-life-scape 'still life' (Grace Glueck, "Chip Hooper: 'California Dreamin', ' "The New York Times, 9 July 1999 , p. E35). This nonce is unneeded because we have the established word still life, which has the added advantage of being shorter.

stonescape is used by Annemarie Koenigsberger in her poem "Praise of a City in the Mountains" (Carol Bulmer, ed., Seven Gates: poetry from Jerusalem 1, Winter 1985, p. 7).

streetscape 'depiction of a street scene'. Hence a kind of cityscape. I have heard a city planner say "we must create a more pleasant streetscape for pedestrians," where reference is not to a depiction.

suburbiascape. See mallscape.

Summerscape. Summerscape ' 85 was the name of the arts festival held by the Huntington Arts Council in 1985 (The New York Times, 23 June 1985, p. 9; in the issue of 22 June 1986, p. 15, the same festival is called Summer 'Scape, which puns on -scape and escaping the summer heat; the festival had been held several times by 1985). Summerscape was the name of an exhibit of works of art depicting summer themes and subjects at the Godwin Ternbach Museum on the campus of Queens College, Flushing, New York, in the summer of 1986. For another allusion to the word escape see Aqua-Escape and for a possible allusion see Yachtscape. 
sunscape 'depiction of the sun or of a scene in which the sun figures prominently'. Sunscape is the name of a group of cooperative townhouses on the beach at Montauk, New York.

Superscape is the name of a certain brand of software.

tablescape 'arrangement of objects on a table to form a decorative display of objects such as toys, books, or bric-a-brac;

the display itself". An illustration called "Tablescapes: The Art of Creative Clutter" accompanied an article about arranging table decorations published in Daily News, New York, of 1 September 1983. "Tablescapes" is the title of an advertizement in The New York Times of 21 November 1999, City Section, p. 20.

Tankscape is the title of an article about water tanks and their workers in Daily News Magazine, New York, 6 March 1988. The word is not used in the article itself.

Teakscapes is the name of a company in Gardiner, New York, that makes teak furniture.

terrorscape. "All this may be a little premature: suburbia, with its inner rings where minorities live and its outer 'edge cities' mostly for whites, is hardly integrated; nor is its petit-bourgeois mentality, founded on insatiable consumerism, any less alive and healthy than previously. Its terrorscapes of undifferentiated big boxes and hurtling traffic, moreover, still do not sit well at some level with a majority of those who live there" (Robert M. Simms, letter to the editor, The New York Times, 14 March 1999, sec. 2, p. 4).

textscape. "At the National Archives of Ontario, one of the microfilm readers had an air sickness bag taped to it; since the seventies, image ergonomists have known of a kind of motion sickness which seems to be caused by the difficulty of visually tracking the creep and lurch of passing textscapes" (Nicholson Baker, "A Reporter at Large: Deadline: The author's desperate bid to save America's past," The New Yorker, 24 July 2000, pp. 42-56 and 58-61; the quotation is from page 55).

Timescape Books is an imprint of Simon and Schuster, an American publisher.

tourist scape. "Lately, I tire of / Long glances / Of tourist scapes" is a line in "From Mount Scopus," a poem in Lami Halperin's Penumbra (Jerusalem, Posner and Sons, 1986, p. 32).

townscape is the British equivalent of cityscape, which is American. See urban landscape and urbanscape.

Tradescape New York, Tradescape.com, TradeScapeCom, Tradescape Corporation, and Tradescape PR are the names of one or more current or former businesses in New York City, at least two of which (Tradescape PR and Tradescape.com) are or were day-trading brokerage firms. Tradescape.com (found in a periodical, the precise details of which I have mislaid) and 
TradeScape Com (found in the 2001-2002 edition of Verizon's Manhattan telephone directory) are alternate names of the same business, it being unclear to me which is official.

travelscape. Www.travelscape.com. is the internet address of "Your online source for discount travel" (advertizement, The New York Times, 9 June 1999, p. A25).

tunescape. "Surveying the Talk-Show Tunescape" is the title of an article by Jon Pareles in The New York Times of 18 February 1994 (pp. C1 and C21), which deals with the live music played on television talk shows. The word is not used in the article itself.

urban landscape and urbanscape ae more or less synonyms of cityscape and townscape. "Looking south of 135th Street, the eye meets the most striking of urbanscapes" (The New York Times, 17 September 1995, sec. 13, p. 20).

Videoscape was the name of a program on CUNY, a New York City television station, at least in 1993.

wallscape "a large photo-crisp advertizement printed by disk onto a lightweight vinyl mesh material and hung flat, like a poster, against the side of a building' (Ann Wozencraft, "Artist Uses New Kind of Canvas: He Prints Ads Suitable for Hanging, from Buildings, "The New York Times, 2 January 2000 , sec. 1 , p. 29). Wailscapes have a precedent: "the erection of elaborate transparencies on public buildings and private houses depicting the long-awaited return of prosperity" (Edwin G. Burrows and Mike Wallace, Gotham: A History of New York City to 1898, New York and Oxford, Oxford University Press, 1999, p. 428, referring to New York City in $1815)$ and "Most impressive was City Hall, $[\ldots]$ covered with glowing transparencies depicting the canal" (idem, p. 431, referring to New York City in 1825).

warscape 'depiction of a war scene'. Hence a hypernym of battlescape.

waterscape is a hypernym of lakescape, marinescape, riverscape, and seascape. Creative Waterscapes is the name of a Connecticut firm that designs and builds swimming pools, ponds, and fountains.

Webscape. "As the nation's cultural institutions start to ponder what they will collect and preserve from the events of Sept. 11, the Internet is figuring largely [sic (D.L.G.)] in their strategies. I Information from the Internet is being continually collected in a major undertaking spearheaded by the Library of Congress. A new Internet site, September 11.archive.org, went on line on Thursday [...]. I The creators of the archive are developing a 'Webscape' feature that, by the end of the month, should enable visitors to assemble an annotated list of select [sic (D.L.G.)] pages -- for instance, the most poignant fire department memorial sites -- and share it with friends via e-mail" (Matthew Mirapaul, "Arts Online: How the Net Is Documenting a Watershed Moment," The New York Times, 15 October 2001, p. E2). At least since December 2000, National Geographic has had a section called Webscapes; it describes websites of interest to its readers.

windowscape 'depiction of a scene from a window'. 
Windscape is the name of an American wind ensemble.

winterscape 'depiction of a winter scene'.

wirescape 'scenery, or a scene, dominated by overhead wires and their supports' (so defined in A Supplement to the Oxford English Dictionary and the second edition of the Oxford English Dictionary).

woodscape 'depiction of a forest scene'. Forestscape is a synonym.

wordscape. "Hinting at the Hint of a Story: Once-Urgent Messages Transform the City Into an Unexpected Wordscape" is the title of an article by Dana Jennings in The New York Times of 24 February 2002 (City Section, p. 24) dealing with personal messages people tack up for one another in public places.

Worldscape was the name of a program on WNYC, a New York City television station, at least in 1993. World Scape was the name of a program on WEDW, a New York City television station, at least in 1993.

xeriscaping 'landscaping in a dry climate' is based on landscaping and thus does not refer to a kind of picture. The noun xeriscape 'garden or park having little need for water' was backformed from xeriscaping.

Yachtscape is the name of "a partial-ownership program in which access to a super-luxe yacht is divided into thirds, while a management company handles everything from providing the crews to catering the cocktail parties to finding the perfect beach for sunbathing in the buff" (Peter Passell, "Vicarious Consumption: Yacht, All Yours, Part Time," The New York Times, 14 June 1998, Business Section, p. 9). This name probably alludes to escape, that is, it suggests that a yacht is the perfect way of escaping the daily grind. For definite allusions to the word escape, see Aqua-Escape and Summer 'Scape.

\section{Notes}

1. This is an expanded version of a note which appeared in American Speech: A Quarterly of Linguistic Usage, vol. 52, nos. 1-2, Spring-Summer 1977, p. 127.

2. Being the oldest and semantically broadest of these words, landscape is also the likeliest to have developed transferred and figurative meanings, as in "In his quest to understand why public spaces work (or don't work), William $\mathrm{H}$. Whyte became, you might say, a streetwalker. He loitered in parks, plazas and subway stations, clipboard in hand, dutifully recording the physical and social landscape" (John Cook, "The Observation of Man: After writing 'The Organizational Man,' his groundbreaking study of corporate culture, he applies his analytical skills to the urban center," The New York Times Magazine, 2 January 2000, p. 23).

On the pronunciations of landscape see pages 184 and 186 of Henry Cecil Wyld's A History of Modern Colloquial English (3 ed., Oxford, Basil Blackwell, 1936; repr. 1953).

3. The 1962 edition, published in Munich, is unavailable to me. 
4. All three writers misetymologize English landscape:

"Landscape (which is Dutch landschap)" makes no sense.

Since Dutch does not have *landscape, "English borrowed the Dutch painting term landscape" is not right.

Because English landscape is adapted from Dutch landschap, Lehrer is not right in saying that it is "from native English sources" (p. 14).

Lest the thought occur to anyone, we note here that Modern English landscape does not descend from Old English landscipe 'region', found (only?) in Genesis B, a ninth-century translation of an Old Saxon passage.

5. My effort to record this word illustrates once again the frequent unreliability of "information" available electronically. I found wordscape when reading a printed edition of The New York Times, clipped the article, mislaid it, called the telephone reference service of the Brooklyn Public Library (the best such service offered by any of New York City's public libraries), was told the word did not appear in a search of the electronic edition of the newspaper, was still sure I had seen it where I thought I had, later found the clipping, called the reference service again out of curiosity whether it could locate the word if I provided an exact bibliographical reference, and was told that the entire subtitle, thus the word too, was missing in the electronic editions of Jennings's article available on the newspaper's Website and elsewhere. A short time before, William Bright had sent me a printout from WorldCat with a complete bibliographical reference for a book published in the 1850s whose subtitle included the word "preport" ("Collected and Preported Under the Direction of the Bureau of Indian Affairs [...]"). Although recognizing it as a reflex of Latin praeportare 'carry in front', I could not make sense of the word in context. Nor did any English dictionary at hand list "preport." An examination of the book itself revealed the word to be Prepared. 